\title{
Mix of Allegedly Functional Components Improves Metabolic Syndrome Risk Factors
}

\author{
Sandra Maria Barbalho, b, e, Maricelma da Silva Soares de Souza ${ }^{a}$, Patricia Cincotto dos Santos Bueno ${ }^{a}$, \\ Elen Landgraf Guiguer ${ }^{\mathrm{a}}$, Flavia Maria Vasques Farinazzi-Machado ${ }^{\mathrm{b}}$, Adriano Cressoni Araujo ${ }^{\mathrm{a}}$, \\ Francelino Aparecido dos Santos ${ }^{\mathrm{b}}$, Gisele Cristina dos Santos ${ }^{\mathrm{b}}$, Ricardo Haddad Adad ${ }^{\mathrm{a}}$, \\ Mariana Fonseca dos Santos ${ }^{\mathrm{a}}$, Claudemir Gregorio Mendes ${ }^{\mathrm{a}}$, Ricardo de Alvares Goulart ${ }^{\mathrm{c}}$, \\ Daniel Pereira Coqueiro ${ }^{\mathrm{d}}$
}

\begin{abstract}
Background: Food is one of the main factors that diminish the risk of development of chronic diseases in humans. In view of this fact, increasing attention has focused on the production and consumption of foods that help reduce this risk. Besides, metabolic syndrome risk factors are increasing in almost all populations of the world. Therefore, the objective of this work was to evaluate the effects of a mixture of ingredients containing textured soy protein, wheat bran, oats, black sesame seeds, white sesame seeds, brown linseed, granola and brown sugar on the biochemical profile, body weight and intestinal motility of Wistar rats.
\end{abstract}

Methods: The experiment involved male rats, which were divided into two groups: one that ingested the mix and the other a control group.

Results: After 40 days of treatment, it was found that body weight, total cholesterol, triglycerides, and glucose levels were reduced and HDL-c increased. Intestinal transit time was also improved.

Conclusion: It was concluded that the use of this mix had beneficial effects on the metabolic profile contributing to the prevention of metabolic syndrome risk factors and improved intestinal transit of Wistar rats.

Keywords: Fibers; Lipemia; Glycemia; Intestinal motility; Wistar rats

\section{Introduction}

The consumption of certain foods has been imputed as one

Manuscript accepted for publication July 23, 2015

aDepartment of Biochemistry and Pharmacology, School of Medicine, University of Marilia, Av. Higino Muzzi Filho 1001, Marilia 15525-902, SP, Brazil ${ }^{b}$ Department of Biochemistry and Nutrition, Faculty of Food Technology of Marilia (FATEC), Av. Castro Alves, 62, Marilia 17506-000, SP, Brazil 'Universitary Hospital, UNIMAR, Av. Higino Muzzi Filho 1001, Marilia 15525902, SP, Brazil

dFAIP, Av. Antonieta Altenfelder, 65, Marilia 17512-130, SP, Brazil

${ }^{\mathrm{e}}$ Corresponding Author: Sandra Maria Barbalho, Alameda dos jatobas, 126, Marilia, SP, Brazil. Email: smbarbalho@terra.com.br

doi: http://dx.doi.org/10.14740/jem292w of the main mechanisms for reducing the risk for the development of chronic and degenerative diseases in humans, whose prevalence has been increasing at an alarming rate. Numerous studies indicate that diets rich in fibers and other bioactive components diminish these risk factors, which include insulin resistance and hyperglycemia, high levels of total cholesterol, LDL-c and triglycerides (TG) and reduced levels of HDL-c [1-4].

Dietetic fibers are resistant to digestion and absorption in the small intestine of humans and are classified as soluble (pectin, gum, mucilage and some hemicelluloses) and insoluble (cellulose, lignin and some hemicelluloses) [5]. Evidence indicates that the ingestion of large amounts of dietetic fibers is significantly associated with lower values of body mass index (BMI), systolic and diastolic blood pressure, and serum LDL-c and triglyceride levels [6-9]. Soluble and insoluble fractions also exert beneficial physiological and metabolic effects in the prevention and treatment of disorders such as intestinal constipation and diverticulitis, and inflammatory processes associated with chronic pathological conditions such as metabolic syndrome (MS), obesity, diabetes mellitus type 2 (DM2), cancer, and cardiovascular diseases (CVD) [10-12].

The ingestion of oily grains such as linseed and sesame, which contain high contents of polyunsaturated fatty acids, dietetic fibers, minerals, vitamins and phytoestrogens also has beneficial effects on human health [13-16].

Considering that disorders such as diabetes and obesity have reached global epidemiological proportions and are one of the main causes of death worldwide, particularly due to cardiovascular complications, the optimization of prevention and control strategies related with the consumption of affordable foods has become a pressing concern $[17,18]$. In response to this concern, several studies have suggested that the association of fibers and phytochemicals (vitamins, minerals, phenolic compounds and phytoestrogens, which are abundant in grains) is more beneficial to health than the activity of fibers consumed isolatedly [19-23]. Hence, the objective of this study was to supplement the diet of Wistar rats with a product prepared from soy protein, wheat bran, oats, sesame seeds, linseed and granola, which are ingredients widely used by the population, and to assess its effects on the biochemical profile, body weight and intestinal motility of these animals. 
Table 1. Mean and Standard Deviation of the Weight of the Animals of the Control Group (CG) and Mix Group (MG) Before and After the Treatment

\begin{tabular}{|c|c|c|c|c|c|}
\hline & \multicolumn{2}{|c|}{ CG } & \multicolumn{2}{|c|}{ MG } & \multirow{2}{*}{ P-value* } \\
\hline & Mean & SD & Mean & SD & \\
\hline Weight before treatment $(\mathrm{g})$ & 224.00 & 13.98 & 231.05 & 11.12 & 0.8679 \\
\hline Weight after treatment (g) & 312.91 & 44.41 & 294.46 & 21.66 & 0.0254 \\
\hline
\end{tabular}

${ }^{*}$ P-value $<0.05$

\section{Materials and Methods}

\section{Preparation of the mix}

The mix of ingredients was prepared in the Food Processing Lab at the Faculty of Technology of Marilia (FATEC), in the state of Sao Paulo, Brazil.

The product was developed from textured soy protein $(14.70 \%)$, wheat bran $(14.70 \%)$, oats $(14.70 \%)$, black sesame seeds $(2.94 \%)$, white sesame seeds $(2.95 \%)$, brown linseed $(5.90 \%)$, granola $(14.70 \%)$ and brown sugar $(29.41 \%)$ purchased in the local market. The granola purchased for this study contained oat flakes, barley malt, inverted sugar, wheat germ, crystal sugar, cashew nuts, corn flakes, soy oil, raisins, soy protein and linseed. All these ingredients were mixed (without crushing) and then heated in an industrial oven (FTE 240, G PANIZ) for $15 \mathrm{~min}$ at a temperature of $120^{\circ} \mathrm{C}$.

\section{Rat groups}

The experiment was approved by the Animal Research Ethics Committee of the University of Marilia (UNIMAR, Marilia, SP, Brazil). Twenty healthy male Wistar rats were used, weighing approximately $230-250 \mathrm{~g}$, which were kept in the vivarium at UNIMAR. The rats were housed in collective cages under a dark/light cycle of $12 \mathrm{~h}$, room temperature of $22 \pm 2{ }^{\circ} \mathrm{C}$, and relative air humidity of $60 \pm 5 \%$. Throughout the experiment, the animals were fed and watered ad libitum, and were cared for according to the recommendations of the Canadian Council's "Guide for the care and use of experimental animals".

After a period of 7 days of acclimation to laboratory conditions, the animals were divided randomly into two experimental groups, which were identified according to the food they would receive: 10 animals were treated with the mix
(MG) and 10 with commercial rat feed (PURINA $\left.{ }^{\circledR}\right)$, constituting the control group (CG). The treatment was applied for 40 consecutive days and the animals were weighed at 2-day intervals.

\section{Preparation of the supplemented rat feed}

The rat feed supplemented with the aforementioned mix was prepared weekly in the Food Processing Lab at the Faculty of Technology of Marilia, UNIMAR, in a proportion of 40:60 mix/commercial feed.

The commercial feed was crushed manually in a plastic mortar and pestle, after which the mix of experimental ingredients and the commercial feed were ground separately in an electric hammer mill operating at 4,500 rpm (MARCONI). After weighing the two constituents separately on a semi-analytical balance, they were mixed homogeneously, using water as binder. Using a meat-filling machine, this mixture was molded into a cylindrical shape identical to that of the commercial feed. The resulting pellets were dried in an air circulating oven (MARCONI) at $65^{\circ} \mathrm{C}$ for about $8 \mathrm{~h}$, stored in polyethylene packaging, and refrigerated until use.

\section{Collection of blood samples and determination of the biochemical profile}

After 40 days of treatment and a 10-h fast, the animals were anesthetized with sodium pentobarbital until complete sedation, after which blood samples were drawn from the vena cava to determine their biochemical profile: total cholesterol (TC), HDL-c, triacylglycerides (TG), glycemia, aspartate aminotransferase (AST) and alanine aminotransferase (ALT).

The exams were carried out at Clinical Analysis Lab of UNIMAR's Hospital (Marilia, SP, Brazil) and the results were interpreted according to the comparison of the CG.

Table 2. Mean and Standard Deviation of Food Consumption by the Animals of the Control Group (CG) and Mix Group (MG) After the Treatment

\begin{tabular}{|c|c|c|c|c|c|}
\hline & \multicolumn{2}{|c|}{ CG } & \multicolumn{2}{|c|}{ MG } & \multirow{2}{*}{ P-value* } \\
\hline & Mean & SD & Mean & SD & \\
\hline Consumption/day at the beginning of the treatment $(\mathrm{g})$ & 11.50 & 3.2 & 11.71 & 2.29 & 0.0767 \\
\hline Consumption/day at the end of the treatment $(\mathrm{g})$ & 13.90 & 2.9 & 11.49 & 1.14 & 0.0223 \\
\hline
\end{tabular}

${ }^{*}$-value $<0.05$ 
Table 3. Mean and Standard Deviation of the Biochemical Variables in the Control Group (CG) and Mix Group (MG)

\begin{tabular}{|c|c|c|c|c|c|}
\hline & \multicolumn{2}{|c|}{ CG } & \multicolumn{2}{|c|}{ MG } & \multirow{2}{*}{$\begin{array}{l}\mathrm{CG} \times \mathrm{MG} \\
\text { P-value* }\end{array}$} \\
\hline & Mean & SD & Mean & SD & \\
\hline Glycemia & 163.20 & 13.74 & 141.00 & 8.21 & 0.00017 \\
\hline $\mathrm{CT}$ & 80.00 & 7.18 & 50.10 & 6.95 & 0.00000 \\
\hline HDL-c & 17.10 & 1.20 & 28.40 & 5.74 & 0.00000 \\
\hline TG & 104.90 & 18.28 & 60.70 & 9.50 & 0.00000 \\
\hline AST & 153.00 & 15.19 & 125.10 & 15.29 & 0.00034 \\
\hline ALT & 76.10 & 16.57 & 60.00 & 8.22 & 0.00654 \\
\hline
\end{tabular}

${ }^{*} \mathrm{P}$-value $<0.05$

\section{Intestinal motility test}

The intestinal motility test was evaluated according to the model described by Michelin and Salgado [24], with modifications. After a 24-h fast, the $\mathrm{CG}$ and $\mathrm{MG}$ were gavage-fed, respectively, $0.3 \mathrm{~mL}$ of saline and $0.3 \mathrm{~mL}$ of the ground cereal mix dissolved in water $(0.3 \mathrm{~g} / \mathrm{mL})$. Then, $45 \mathrm{~min}$ later, the two groups were gavage-fed $0.3 \mathrm{~mL}$ of a $10 \%$ activated charcoal suspension in 5\% gum arabic. Four hours after the administration of activated charcoal, the animals were euthanized with a lethal intraperitoneal injection of $200 \mathrm{mg} / \mathrm{kg}$ of thiopental. After death was confirmed, the intestines were removed, pinned to a styrofoam board, their length and the distance traveled by the activated charcoal in the intestines of each group were measured with a tape measure.

\section{Analysis of the percent composition}

The rat feed supplemented with the mix was evaluated in terms of its moisture content (total dry extract) by the gravimetric method in an oven at $105^{\circ} \mathrm{C}$ for $16 \mathrm{~h}$ until it reached a constant weight; lipids were evaluated by Soxhlet extraction; total nitrogen by the Kjeldahl method, multiplying the values of total nitrogen by 6.25 to obtain the equivalent values in protein; ashes in a muffle furnace at $550{ }^{\circ} \mathrm{C}$; carbohydrates by difference,

Table 4. Results of the Analysis of the Percent Composition of the Mix of Ingredients

\begin{tabular}{lll}
\hline Determinations (\%) & Results & \% VD* \\
\hline Moisture & 2.41 & - \\
Ashes & 3.15 & - \\
Lipids & 15.40 & 28 \\
Carbohydrates & 44.22 & 14.74 \\
Proteins & 15.34 & 20.45 \\
Crude fiber & 19.48 & 77.92 \\
Energy value† & 376.84 & - \\
\hline
\end{tabular}

*Daily reference values based on a diet of $2,000 \mathrm{kcal}$ or $8,400 \mathrm{~kJ}$. †kcal $/ 100 \mathrm{~g}$ of the product, according to Atwater factors: $9 \mathrm{kcal} / \mathrm{g}$ of lipids, $4 \mathrm{kcal} / \mathrm{g}$ of protein and $4 \mathrm{kcal} / \mathrm{g}$ of carbohydrates. as well as crude fiber [25]. All the analyses were performed in triplicate.

\section{Statistical analysis}

BioEstat version 5.0 software was used for the statistical analysis and the variables are presented as mean and standard deviation (SD). The comparison between the $\mathrm{MG}$ and $\mathrm{CG}$ was complemented by Student's $t$-test, adopting a 5\% level of significance.

\section{Results}

The results of the variations in the animals' weight (Table 1) indicated that at the end of the treatment, the weight of the treated group was significantly lower than that of the CG.

Table 2 describes the food consumption of the animals at the beginning and end of the treatment period. Note that the food consumption of two groups did not differ at the beginning of the study, but that by the end of this period the treated group had reduced its consumption significantly in comparison to the CG.

Table 3 shows the results of the biochemical variables. As can be seen, there was a significant reduction in the $\mathrm{TC}, \mathrm{TG}$, AST, ALT and glycemia levels and a significant increase in the HDL-c levels.

The results of the analysis of the percent composition show high values of carbohydrates and crude fiber in the formulation used in the experiment (Table 4). Considering that the animals' initial food consumption was $11.71 \mathrm{~g}$, which corresponds to $4.68 \mathrm{~g}$ of the mix of ingredients (40:60), these results indicate that the animals' daily consumption of dietetic fiber was ap-

Table 5. Mean and Standard Deviation of the Percentage of Distance Traveled in the Large Intestine of Wistar Rats After Ingestion of the Mixture by the Control Group (CG) and Mix Group (MG)

\begin{tabular}{llll}
\hline & CG & MG & P-value* \\
\hline$\%$ traveled & $73.38 \pm 7.37$ & $97.18 \pm 4.61$ & 0.0001 \\
\hline
\end{tabular}

${ }^{*}$ P-value $<0.05$ 
proximately $0.92 \mathrm{~g}$.

Table 5 lists the intestinal motility rates. The percentage of distance traveled in the intestines of the MG was greater (15.82 \%) than in the CG.

\section{Discussion}

The consumption of the formulation used in this study led to a significant decline in weight gain and food consumption of the treated animals (MG). The soy protein, wheat bran and oats in the mix are foods rich in alimentary fibers, which are known to affect body weight. Morenga et al [26] used diets rich in proteins and in fibers for obese patients and observed weight loss in both groups, but this loss was higher in the group on the protein-rich diet.

Other studies have demonstrated the influence of the quality of the diet and of the protein and fiber content on body weight, which is consistent with the results found in this work. The effect of fibers is visible immediately during ingestion, since they increase the mastication time and flow of gastric juices, while the hydration caused by the presence of saliva increases the volume of gastric content, and also hastens and prolongs the body's sensation of satiety, promoting reduced energy intake and a consequent reduction in weight gain $[5$, $8,9,27,28]$.

At the end of the treatment, the glucose, TC and TG levels of the MG were significantly lower than those of the CG, and the HDL-c levels were significantly higher, indicating the relevance of the consumption of these components for the prevention and control of risk factors for diabetes and its cardiovascular complications. Weickert et al [29] demonstrated that a diet with high fiber content improved insulin sensitivity by $25 \%$ when compared to a protein-rich diet. Fibers also reduce the glycemic index, contributing to the prevention of risk factors for food-related disorders such as diabetes [23, 30, 31].

Studies have shown that the use of linseed (Linum usitatissimum) helps lower glycemia and plasma lipids, and increase HDL-c levels [14, 15, 32, 33]. Linseed contains soluble (40\%) and insoluble (60\%) dietetic fibers that have lipid-lowering activity, including mechanisms that reduce the absorption of cholesterol through the action of viscous gel-forming soluble fibers. Lignins may be responsible for the reducing lipid concentrations. Their metabolites in the organism can bind to bile acids and other chemical compounds such as cholesterol, retarding or diminishing the absorption of these compounds [34-36].

The lipid-lowering effects of linseed can also be attributed to the presence of essential fatty acids $\omega 3$ and $\omega 6$. Thus, because its omega fatty acids are associated with lignins and vitamins, linseed is considered a functional food with potential antiatherogenic effects [35, 36]. Kaithwas et al [37] demonstrated that Linum usitatissimum fixed oil possesses anti-inflammatory, analgesic and antipyretic activities.

The consumption of oats (Avena sativum), wheat bran (Triticum aestivum) and granola also has positive effects on dyslipidemia in rats and humans. The effects produced by oats are due to the presence of $\beta$-glucans, which are resistant to digestive processes, forming viscous solutions in contact with water [38, 39]. Moreover, being pseudoplastic, they slow down digestion, hindering the interaction of pancreatic enzymes with the substrate, thus diminishing the digestion of carbohydrates by pancreatic amylase and reducing the absorption rate of these molecules in the digestive tract. Wheat bran is composed of about $76 \%$ of insoluble fibers (cellulose and hemicellulose) and contains several phenolic compounds that act as antioxidants, giving it important properties for the inhibition of LDL-c oxidation and thus reducing the risk for CVD [40, 41].

Visavadiya and Narasimhacharya [42] and Mirmiran et al [43] studied the effects of supplementation with sesame (Sesamum indicum) and found lipid and glycemia-lowering effects.

Epidemiological studies have demonstrated the effects of whole grains in reducing the incidence of diabetes type 2, CVD and other chronic disorders, since their compositions contain not only vitamins and minerals but also phenolic compounds, phytoestrogens and other phytochemicals with metabolic properties beneficial in reducing lipid variables, oxidative stress and inflammatory activity $[42,44]$. These components are found in sesame, oats, wheat, linseed and granola and can contribute to improve the glycemic profile, as indicated in this study.

Together with fibers, grain-derived proteins seem to contribute considerably to the reduction of TC, as well as other plasma lipids. Soy is considered an important source of protein and several mechanisms of action have been attributed to its bioactive substances, such as flavonoids, and soluble and insoluble fibers, which explain its effect on lipid metabolism [45].

The decrease in cholesterol resulting from the action of soy protein is due to the fact that it is not completely degraded by the digestive enzymes, resulting in the formation of peptides, which can act upon the endogenous cholesterol metabolism and/or may possess properties similar to those of fibers, determining the formation of insoluble complexes with cholesterol that are excreted in stool. Soluble fibers are almost completely fermented in the colon, producing short chain fatty acids that can inhibit hepatic cholesterol synthesis and increase LDLc clearance. Other authors $[29,44,46]$ demonstrated that the use of soy protein has a lipid-lowering effect in animals.

Elevated blood levels of transaminases indicate the destruction of liver cells. No such alterations were observed in the present study, indicating that, in the amounts administered to the animals, the mix is safe for consumption [47].

As for intestinal motility, it was found that the distance covered by the activated charcoal from the pylorus to the beginning of the cecum was greater in the rats that consumed the mix (Table 5). This can be attributed to the strong presence of insoluble fibers in the constituents of the mix (Table 4). Dietetic fibers interfere in the weight and consistency of stool, augmenting its motility and diminishing the intestinal transit time, as well as increasing the frequency of bowel evacuation. Chan et al [48] state that a diet rich in fibers is necessary to normalize bowel movements and help form the fecal bolus, claiming that a fiber-rich diet should be part of the treatment of mild constipation. In fact, after evaluating 33 patients with functional constipation, these authors demonstrated that the ingestion of fibers in the diet increased their bowel movements and reduced the need for laxatives. In another study, the sub- 
jects received a mixture of breakfast cereals containing 25.0 - $28.7 \mathrm{~g}$ of fibers daily for 3 weeks, after which a reduction in the intestinal transit time and a significantly higher frequency of bowel movements were observed [49].

Insoluble fibers have a mechanical effect on the gastrointestinal tract, presenting a low degree of fermentation. By incorporating water (albeit to a lesser extent that soluble fibers), they increase the fecal bolus, facilitate fecal excretion and reduce the intestinal transit time. Since their degradation by bacterial colonies is difficult, they are eliminated almost intact in the feces [50]. The use of the mixture of ingredients in this study promoted a significant increase in the space covered in the large intestine when compared to the control, indicating that it may be helpful in the treatment and prevention of bowel constipation. This problem is associated to one of the most prevalent disorders found by doctors and promotes a negative impact on quality of life.

\section{Conclusions}

It was concluded that the mix of soy protein, wheat bran, oats, sesame, linseed and granola, when included in the diet of Wistar rats, had beneficial effects on their body weight and lipid and glycemic profiles, as well as a positive effect in increasing the distance covered in the intestinal transit of these animals. With these results it is possible to say that this mix can prevent or can improve the risk factors of MS, reducing the occurrence of diabetes and CVD. Studies with humans are needed in order to evaluate the occurrence of the same benefits observed in this experimental model.

\section{Conflict of Interests}

This work was not supported by any research funding agency. There is no conflict of interest.

\section{References}

1. McRorie JW, Jr. Evidence-Based Approach to Fiber Supplements and Clinically Meaningful Health Benefits, Part 2: What to Look for and How to Recommend an Effective Fiber Therapy. Nutr Today. 2015;50(2):90-97.

2. Lin LY, Peng CC, Yeh XY, Huang BY, Wang HE, Chen KC, Peng RY. Antihyperlipidemic bioactivity of Alpinia officinarum (Hance) Farw Zingiberaceae can be attributed to the coexistance of curcumin, polyphenolics, dietary fibers and phytosterols. Food Funct. 2015;6(5):1600-1610.

3. He LW, Meng QX, Li DY, Zhang YW, Ren LP. Meat quality, oxidative stability and blood parameters from Graylag geese offered alternative fiber sources in growing period. Poult Sci. 2015;94(4):750-757.

4. Mehta N, Ahlawat SS, Sharma DP, Dabur RS. Novel trends in development of dietary fiber rich meat productsa critical review. J Food Sci Technol. 2015;52(2):633647.

5. Campbell A. Probiotics and prebiotics: parts of a healthy diet. Diabetes Self Manag. 2011;28(4):9-10, 12, 14-16.

6. Moreno Franco B, Leon Latre M, Andres Esteban EM, Ordovas JM, Casasnovas JA, Penalvo JL. Soluble and insoluble dietary fibre intake and risk factors for metabolic syndrome and cardiovascular disease in middle-aged adults: the AWHS cohort. Nutr Hosp. 2014;30(6):12791288.

7. Keithley JK, Swanson B, Mikolaitis SL, DeMeo M, Zeller JM, Fogg L, Adamji J. Safety and efficacy of glucomannan for weight loss in overweight and moderately obese adults. J Obes. 2013;2013:610908.

8. Weitkunat K, Schumann S, Petzke KJ, Blaut M, Loh G, Klaus S. Effects of dietary inulin on bacterial growth, short-chain fatty acid production and hepatic lipid metabolism in gnotobiotic mice. J Nutr Biochem. 2015.

9. Ou X, Andres A, Pivik RT, Cleves MA, Badger TM. Brain gray and white matter differences in healthy normal weight and obese children. J Magn Reson Imaging. 2015.

10. Rodriguez-Leyva D, Weighell W, Edel AL, LaVallee R, Dibrov E, Pinneker R, Maddaford TG, et al. Potent antihypertensive action of dietary flaxseed in hypertensive patients. Hypertension. 2013;62(6):1081-1089.

11. Kraja B, Muka T, Ruiter R, de Keyser C, Hofman A, Franco OH, Stricker BH, et al. Dietary Fiber Intake Modifies the Positive Association between n-3 PUFA Intake and Colorectal Cancer Risk in a Caucasian Population. J Nutr. 2015.

12. Sanchez Almaraz R, Martin Fuentes M, Palma Milla S, Lopez Plaza B, Bermejo Lopez LM, Gomez Candela C. [Fiber-type indication among different pathologies]. Nutr Hosp. 2015;31(6):2372-2383.

13. Grindel A, Staps F, Kuhnt K. Cheek cell fatty acids reflect n-3 PUFA in blood fractions during linseed oil supplementation: a controlled human intervention study. Lipids Health Dis. 2013;12:173.

14. Edel AL, Rodriguez-Leyva D, Maddaford TG, Caligiuri SP, Austria JA, Weighell W, Guzman R, et al. Dietary flaxseed independently lowers circulating cholesterol and lowers it beyond the effects of cholesterol-lowering medications alone in patients with peripheral artery disease. J Nutr. 2015;145(4):749-757.

15. Haliga RE, Mocanu V, Badescu M. Antioxidative and antiatherogenic effects of flaxseed, alpha-tocopherol and their combination in diabetic hamsters fed with a high-fat diet. Exp Ther Med. 2015;9(2):533-538.

16. John J, Nampoothiri M, Kumar N, Mudgal J, Nampurath GK, Chamallamudi MR. Sesamol, a lipid lowering agent, ameliorates aluminium chloride induced behavioral and biochemical alterations in rats. Pharmacogn Mag. 2015;11(42):327-336.

17. Al-Lawati JA, Panduranga P, Al-Shaikh HA, Morsi M, Mohsin N, Khandekar RB, Al-Lawati HJ, et al. Epidemiology of Diabetes Mellitus in Oman: Results from two decades of research. Sultan Qaboos Univ Med J. 2015;15(2):e226-233.

18. Mattei J, Malik V, Wedick NM, Hu FB, Spiegelman D, Willett WC, Campos H. Reducing the global burden of type 2 diabetes by improving the quality of staple foods: The Global Nutrition and Epidemiologic Transition Ini- 
tiative. Global Health. 2015;11(1):23.

19. Tagliaferri C, Davicco MJ, Lebecque P, George S, Amiot MJ, Mercier S, Dhaussy A, et al. Olive oil and vitamin D synergistically prevent bone loss in mice. PLoS One. 2014;9(12):e115817.

20. Kongkachuichai R, Charoensiri R, Yakoh K, Kringkasemsee A, Insung P. Nutrients value and antioxidant content of indigenous vegetables from Southern Thailand. Food Chem. 2015;173:838-846.

21. Basu S, Das M, Sen A, Choudhury UR, Datta G. Analysis of complete nutritional profile and identification of bioactive components present in Alocasia indica tuber cultivated in Howrah District of West Bengal, India. Asian Pac J Trop Med. 2014;7S1:S527-533.

22. Liu RH. Dietary bioactive compounds and their health implications. J Food Sci. 2013;78: 18-25.

23. Jenkins AL, Kacinik V, Lyon M, Wolever TM. Effect of adding the novel fiber, PGX(R), to commonly consumed foods on glycemic response, glycemic index and GRIP: a simple and effective strategy for reducing post prandial blood glucose levels--a randomized, controlled trial. Nutr J. 2010;9:58.

24. Michelin DC, Salgado HRM. Avaliacao da atividade laxante de Operculina macrocarpa L. Urban (Convolvulaceae). Rev Bras Barmacogn. 2004;14(2):15-109.

25. Zenebon O, Pascuet NS, Tiglea P. Instituto Adolfo Lutz (Adolfo Lutz Institute - Sao Paulo). Physical and chemical methods for food analysis. Sao Paulo, Brasil, 2008.

26. Arabshahi S, van der Pols JC, Williams GM, Marks GC, Lahmann PH. Diet quality and change in anthropometric measures: 15-year longitudinal study in Australian adults. Br J Nutr. 2012;107(9):1376-1385.

27. Te Morenga LA, Levers MT, Williams SM, Brown RC, Mann J. Comparison of high protein and high fiber weight-loss diets in women with risk factors for the metabolic syndrome: a randomized trial. Nutr J. 2011;10:40.

28. Jones JM. Dietary fiber future directions: integrating new definitions and findings to inform nutrition research and communication. Adv Nutr. 2013;4(1):8-15.

29. Weickert MO, Roden M, Isken F, Hoffmann D, Nowotny P, Osterhoff M, Blaut M, et al. Effects of supplemented isoenergetic diets differing in cereal fiber and protein content on insulin sensitivity in overweight humans. Am J Clin Nutr. 2011;94(2):459-471.

30. Zhang L, Li HT, Shen L, Fang QC, Qian LL, Jia WP. Effect of Dietary Resistant Starch on Prevention and Treatment of Obesity-related Diseases and Its Possible Mechanisms. Biomed Environ Sci. 2015;28(4):291-297.

31. Krog-Mikkelsen I, Sloth B, Dimitrov D, Tetens I, Bjorck I, Flint A, Holst JJ, et al. A low glycemic index diet does not affect postprandial energy metabolism but decreases postprandial insulinemia and increases fullness ratings in healthy women. J Nutr. 2011;141(9):1679-1684.

32. Hutchins AM, Brown BD, Cunnane SC, Domitrovich SG, Adams ER, Bobowiec CE. Daily flaxseed consumption improves glycemic control in obese men and women with pre-diabetes: a randomized study. Nutr Res. 2013;33(5):367-375.

33. Kristensen M, Jensen MG, Aarestrup J, Petersen KE, Son- dergaard L, Mikkelsen MS, Astrup A. Flaxseed dietary fibers lower cholesterol and increase fecal fat excretion, but magnitude of effect depend on food type. Nutr Metab (Lond). 2012;9:8.

34. Almario RU, Karakas SE. Lignan content of the flaxseed influences its biological effects in healthy men and women. J Am Coll Nutr. 2013;32(3):194-199.

35. Francis AA, Deniset JF, Austria JA, LaVallee RK, Maddaford GG, Hedley TE, Dibrov E, et al. Effects of dietary flaxseed on atherosclerotic plaque regression. Am J Physiol Heart Circ Physiol. 2013;304(12):H1743-1751.

36. Makni M, Sefi M, Fetoui H, Garoui el M, Gargouri NK, Boudawara T, Zeghal N. Flax and Pumpkin seeds mixture ameliorates diabetic nephropathy in rats. Food Chem Toxicol. 2010;48(8-9):2407-2412.

37. Ferreira RS, Cassaro DC, Domingos H, Pontes ERJC, Aiko PH, Meira JEC. The effects of a diet formulation with oats, soybeans, and ?ax on lipid pro?les and uricemia in patients with AIDS and dyslipidemia. Rev Soc Bras Med Trop. 2013;46:691-697.

38. Kaithwas G, Mukherjee A, Chaurasia AK, Majumdar DK. Antiinflammatory, analgesic and antipyretic activities of Linum usitatissimum L. (flaxseed/linseed) fixed oil. Indian J Exp Biol. 2011;49:932-940.

39. Mira GS, Graf H, Candido LMB. In retrospect, with emphasis on dietary fiber beta-glucan in the treatment of diabetes. Braz J Pharm Sci. 2009;45:11-20.

40. Kothari S, Jain AK, Mehta SC, Tonpay SD. Hypolipidemic effect of fresh Triticum aestivum (wheat) grass juice in hypercholesterolemic rats. Acta Pol Pharm. 2011;68(2):291294.

41. Regand A, Tosh SM, Wolever TM, Wood PJ. Physicochemical properties of beta-glucan in differently processed oat foods influence glycemic response. J Agric Food Chem. 2009;57(19):8831-8838.

42. Visavadiya NP, Narasimhacharya AVRL. Sesame as a hypocholesteraemic and antioxidant dietary component. Food Chem Toxicol. 2008;46:1889-1895.

43. Mirmiran P, Bahadoran Z, Golzarand M, Rajab A, Azizi F. Ardeh (Sesamum indicum) could improve serum triglycerides and atherogenic lipid parameters in type 2 diabetic patients: a randomized clinical trial. Arch Iran Med. 2013;16(11):651-656.

44. Barbalho SM, Farinazzi-Machado FMV. Soybean: food or remedy? In Soybean and Nutrition (Hany El-Shemy editor). Publisher: InTech. 411,2011.

45. Xiao, CW, Wood CM, Weber D, Aziz SA, Mehta R, Griffin P, Cockell KA. Dietary supplementation with soy isoflavones or replacement with soy proteins prevents hepatic lipid droplet accumulation and alters expression of genes involved in lipid metabolism in rats. Genes Nutr. 2014;373:1-12.

46. Takahashi A, Okazaki Y, Nakamoto A, Watanabe S, Sakaguchi H, Tagashira Y, Kagii A, et al. Dietary anthocyanin-rich Haskap phytochemicals inhibit postprandial hyperlipidemia and hyperglycemia in rats. J Oleo Sci. 2014;63(3):201-209.

47. Cai C, Cao Z, Loughran PA, Kim S, Darwiche S, Korff S, Billiar TR. Mast cells play a critical role in the systemic 
inflammatory response and end-organ injury resulting from trauma. J Am Coll Surg. 2011;213(5):604-615.

48. Chan AO, Leung G, Tong T, Wong NY. Increasing dietary fiber intake in terms of kiwifruit improves constipation in Chinese patients. World J Gastroenterol. 2007;13(35):4771-4775.

49. Vuksan V, Jenkins AL, Jenkins DJ, Rogovik AL, Sievenpiper JL, Jovanovski E. Using cereal to increase dietary fiber intake to the recommended level and the effect of fiber on bowel function in healthy persons consuming North American diets. Am J Clin Nutr. 2008;88(5):1256-1262.

50. Timm D, Willis H, Thomas W, Sanders L, Boileau T, Slavin J. The use of a wireless motility device (SmartPill(R)) for the measurement of gastrointestinal transit time after a dietary fibre intervention. Br J Nutr. 2011;105(9):13371342. 